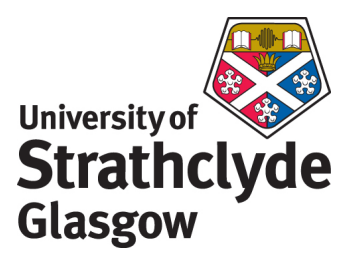

Stewart, Paul and Martinez Lucio, M. (2010) Collective narratives and politics in the contemporary study of work: the new management practices debate. Work, Employment and Society . ISSN 0959-0170

http://strathprints.strath.ac.uk/28075/

This is an author produced version of a paper published in Work, Employment and Society . ISSN 0959-0170. This version has been peer-reviewed but does not include the final publisher proof corrections, published layout or pagination.

Strathprints is designed to allow users to access the research output of the University of Strathclyde. Copyright $(C$ and Moral Rights for the papers on this site are retained by the individual authors and/or other copyright owners. You may not engage in further distribution of the material for any profitmaking activities or any commercial gain. You may freely distribute both the url (http://strathprints.strath.ac.uk) and the content of this paper for research or study, educational, or not-for-profit purposes without prior permission or charge. You may freely distribute the url (http://strathprints.strath.ac.uk) of the Strathprints website.

Any correspondence concerning this service should be sent to The Strathprints Administrator: eprints@cis.strath.ac.uk 


\section{Collective Narratives and Politics in the Contemporary Study of Work: The New Management Practices debate}

In this article we explore the question of how as sociologists of work we might research those who constitute the substance of our labour process. We approach this question through an examination of the New Management Practices debate, principally in the labour movement where a distinctive and critical view of NMP developed in the late 1980s. Second, we argue that there is a link between this debate and the wider politics of labour process discussion both within and beyond the labour movement which has witnessed a shift away from an earlier engagement with worker interventions. In response we suggest the need to re-evaluate the nature of academic engagement with labour thus reanimating a closer engagement with labour-in-work and collective worker narratives.

Our central question is this: how, as researchers, we can explore the labour processes of those who constitute the substance of our labour process. How do we research labour? We attempt to illustrate this through an understanding of the trajectory of the so-called New Management Practices (NMP) debate, which took off in the late 1980s. By new management practices we are referring to the panoply of work place changes summed up under the broad notion of HRM. For many, such developments represented a major turn in the way management was addressing personnel affairs and defined a new "pernicious agenda' (Keenoy, 1990). While involving technological changes to production, inter alia, teamwork, quality circles, continuous improvement programmes, their principal concern was with new ways to manage-subordinate labour in the context of trade union quiescence or exclusion. In brief, they were designed to change the focus of work place relations from a union to an employer driven agenda. We want to exemplify this moment because it drew upon the resources of a range of engagés including worker-intellectualactivists that we might describe collectively, in Gramsci's terms, as labour movement organic intellectuals. Interestingly, works based worker responses, once prominent in this debate within and without the labour movement, have become less audible. Thus, to research labour, we suggest, assumes participation with labour as committed scholar activists (Bourdieu, 2003) and that, moreover, the history of the NMP debate shows how this can be done and the extent to which from the point of view of labour this might achieve some success, i.e. through a recommitment to a 'turn to labour' and its sometimes oppositional stance which is, arguably, part of an emancipatory project.

Associated with this move away from what was sometimes perceived to be a radicaloppositional stance is the way the debate has focused on outcomes, occasionally in isolation of context. Furthermore, this is partly associated, ironically, with the increasing role within the academy of the very NMPs more easily derided in other labour processes by academics. In response to these shifts we need to re-evaluate the nature of academic engagement with labour-in-work in the context of workplace subordination and dissonance often left out by the 'official' voices of labour, broadly speaking. We argue that a project of critical public engagement, which Burawoy (2005) would describe in terms of "Public Sociology" allows support for those subordinated by work and the labour process. 
In the approach we seek to advance, to explicitly articulate the voices and narratives of the excluded and to elaborate their critical views (not necessarily the same thing) we also require attention to alternative and independent narratives. Specifically, we are referring to literature and initiatives developed by worker activists but this also includes (below) training and seminar resources that have been independently developed at the local level, and alternative media oriented materials and the working through of this in terms of shop floor practices and strategies. It is the active and conscious worker voice and their place in the constitution of narratives of collective interventions and practices that concerns us here. We seek to highlight patterns of collective expressions of what work does to people, their various struggles to make sense of this together with their practical struggles against it. We would see this as constituting a vital element of what Ossewaarde (2007: 800) describes as the contemporary new sociology driven by the desire for an understanding of the needs of the excluded. Ossewaarde argues this oeuvre constitutes a "moral and emancipatory enterprise" requiring the utilisation of research methods antithetical to positivist research agendas.

Hence, the paper focuses on a particular moment of the discussion and experience of change at work. During the late 1980s and early 1990s a series of academic interventions set in motion a discussion of what were taken to be new forms of managerial control at work (inter alia, teamwork and individualised payment systems). Debates amongst some within the academy were paralleled within the labour movement where trade unionists were witnessing an array of changes in managerial approaches to workplace control. These reflected the dynamics of neo-liberal policies and market oriented approaches to managing labour. What was going on in the workplace was therefore part of a broader debate amongst activists and academics. An important feature of this labour movement interest was the fact that local activists and trade union research departments, essentially the organic intellectuals of the labour movement, drove initiatives in critical understanding of the new phenomena. There was, for example, a significant link between new forms of management practices and the theme of deteriorating health as a consequence of new work regimes. We go on to argue that towards the end of the 1990s a greater focus on questions of performance and efficiency began to prevail in aspects of the debate. Many of these interventions began to look at the role of new forms of management control within the workplace of such new organizational spaces. In many ways, the NMP debate was reborn, as we will show, but de-contextualised from the myriad social antagonisms in which it is enmeshed.

In terms of structure, therefore, we begin by presenting an outline of a discussion of NMP in the labour movement through reference to some brief cases, especially that of car manufacturing and postal services. In the first section, our argument is that worker intellectuals and scholar activists (organic intellectuals) constituted a debate, which was both a practical and intellectual response to NMPs. This was a radical and innovative agenda and our point is that while traditional intellectuals in the academy subsequently responded to NMPs alongside officials within organised labour, a more conciliatory view of NMPs took shape which undermined these autonomous debates. Following this, in the second section, the paper offers an account of the implications of this latter view on labour process discussions within and beyond the labour movement. In this second 
section the various dynamics that have limited collective independent worker voices from key aspects of the academic discussion on NMP are addressed. Finally, in the third section, through a discussion of alternative perspectives, we suggest the need for closer engagement between worker-intellectual-activists and scholar-activists.

\section{1: Framing the New Politics of Production ${ }^{1}$ : origins and character of a labour movement response in the 1980s and 1990s}

The critical discussions in the late 1980s and 1990s on NMP brought together academics and labour movement researchers but also many shop floor activists. A number of critical, labour sympathetic, researchers had already given attention to aspects of the character of a new management agenda, which claimed both a paradigmatic break and enhanced worker experience of the employment relationship (O'Connell Davidson, 1990; Smith, 1994; Beale, 1994; Delbridge et al. 1992. See below p4). A number of mantras were forged which would account for the latter along with improved company performance via, most notably, teamwork, performance measurement, and evaluation of individual performance. We are all familiar with these and many of them (inter alia 'onebest-way', 'working-smarter-not-harder') have become important elements in the new management assault on labour standards and union organization. It is axiomatic of much labour movement and radical academic critiques that these imperatives perform the dual roles of ideological under-labourer to, and the substantive form taken by, neo-liberalism in and at work. Not surprisingly, commentary and analysis emerges where NMPs impact upon worker experience, most obviously in terms of worker QWL, and most usually in the strategic discussion on health and safety.

In an earlier reflection on this moment, which we termed a New Politics of Production (Stewart and Martinez Lucio, 1998), we argued that it was precisely in the interstices of labour, labour movement and management engagement that the possibilities for worker and trade union development in the context of neo-liberalism were made explicit. In the present period the current dénouement of work place engagement with the politics of NMPs has highlighted the opening up of two spaces, one delineated by moments of compromise around business and service union agendas, and another, by the content and expanse of a new agenda of workplace struggle engendered with and by the recomposition of the organic intellectual. Moreover, the debate must consider the question of what it is that we research and the means by which we conduct our research (below). Making sense of restructuring and labour engagement can be better understood if we locate them in a broader discussion of the way NMP were historically understood within the labour movement. There is a very interesting story of the way in which the TGWU (UNITE) came to the NMP debate (Martinez Lucio and Weston, 1992; Stewart et al, 2009).

At the end of the 1980s, a number of TGWU regions with responsibility for members in the auto sector began to develop a distinctive critique of the NMP. Fascinatingly, this critical agenda was developed first at plant level. A number of key union activists, many of them long standing stewards, who continued to work on the assembly lines, had noticed the synchrony of proposed technical and organisational change. Unlike previous 
attempts to address the balance of forces in the assembly plants, management was eschewing direct confrontation in favour of a more strategic approach encompassing a new discourse using a 'worker'-centred vocabulary of involvement (Stewart et al, 2009). This was much more than the traditional nostrums of EI; the new approach became the basis for a range of new management narratives - NMP. Significantly, workers increasingly were reporting health problems on the lines. ${ }^{2}$ Together with the Transnational Information Exchange (TIE) ${ }^{3}$, stewards from GM-Vauxhall, Ford, Rover and Peugeot-Citroen organised four international conferences on NMPs and their impact on the shop floor but they also addressed the fundamental question of the character and trajectory of NMP on unions and worker organisation. In parallel, T\&G stewards at Vauxhall-GM, developed a radical agenda for confronting NMP with the support of the Labor Notes current in the US. This interaction with a radical labour undercurrent was of inestimable value to the campaign to defend the union. (Stewart, et al 2009)

Significantly, the conclusions reached by the T\&G at Vauxhall-GM were similar to those offered in Parker, Slaughter and Moody's, Labor Notes prognosis. These were that NMP, constituted a new form of management control which if not always reaching for anti-union rhetoric, understood the shop floor as the battlefield in pursuit of a new management hegemony. If workers, themselves, could be won to a company agenda (lean production) the attitude of trade unions would be irrelevant. This is where a number of academics, such as Jones (1992) and Oliver et al (1994) played a vital role in naturalising lean production and notably because of their institutional role in providing it with intellectual credibility: arguably because it would be imbued with the scientific authenticity deriving from the 'academy'. However, a range of labour movement intellectuals continued to challenge such managerialist frames of analysis. Any assessment of the import of the latter response must take note of the vital work of critical mainstream scholars working inside the academic whose research focussed upon challenging many of the nostrums of pro-NMPs scholars. We include the vital work of, inter alia, Webb, 1996; Williams et al, 1992; Berggren, 1993; Gottfried, 1992. This counter-oeuvre still represents the salient critique of NMP although by the late 1990s it was socially and politically enriched by the strategic prognoses of the Canadian Auto Workers and their path breaking response; in effect a successful, if only briefly, practical counter attack on lean on the shop floor (Rinehert et al 1997). In the UK, stewards became increasingly prominent in this debate (Stewart and Wass, 1996) as did their counterparts in continental Europe as a result of the TIE and related information networks (Martinez Lucio and Weston, 1996). The new politics of production were characterised by shop floor debate about the social and political character of NMP, regarded by management and labour alike as lean production.

By contrast, the TGWU's events on lean, inevitably tended towards more institutionalised concerns around the way that union interpretation of lean (NMPs) might be company 'friendly'. The thinking went something like this: if unions might understand what lean was about and organise adequate defences they would be better placed to issue sound and 'sensible' advice to management about the best way to simultaneously protect the firm and workers rights and jobs. Thus, at the end of 1992, the TGWU organised the largest international conference to date on lean production ${ }^{4}$. Speakers included 
proponents of NMP, including the IMVP guru Dan Jones, Nissan's Director of Personnel together and other spokespersons from GM and Rover. (To offer some balance to this debate David Robertson from the CAW offered a fundamental critique of the whole lean agenda.) Yet if the trade union line at the national level was that lean was revolutionary yet negotiable - ironically mirroring the line of the evangelists in the corporation and the traditional intellectuals in the academy - then it would become impossible to challenge its fundamentals.

However, many participants, especially those aligned to TIE, searched for an oppositional critique based on the view that lean production-NMP, was essentially a deeper form of work place control: capital was driving labour across a number of aspects of workers' lives reflected increasingly in the deterioration of aspects of the quality of working life. The emerging view was that workers' health was potentially the Achilles Heel of the NMPs. Specifically, organic intellectuals in the labour movement began to play a vital role in the formulation of this space of opposition through documentation, seminars and steward training that led to the development of oppositional narratives and practices. ${ }^{5}$

In other cases where critical debates on NMP were driven by local activists allied to individuals or organisations, a similar process of steadily undermining or softening their critique by elements within the national leadership was witnessed. The Post Office's union in the 1990s was heavily influenced by the critical debate in other unions such as the TGWU on NMP as the employer began to introduce TQM and team working as part of the transformation of workplace organisation (Martinez Lucio et al, 2000). Various workplace activists felt - although not all - that NMP were a precursor to privatisation and the fragmentation of the Post Office into different businesses. In fact Quality Management programmes were training all postal workers on understanding the market and its 'needs'. Given this, a similar dynamic emerged within the union in terms of the activist training being developed to 'de-mystify' NMP and make it palatable and 'manageable' from a trade union perspective. In fact this training in the mid to late 1990s drew on the training department of the TGWU, which had begun to develop a 'critical but engaging' perspective as we outlined above. Hence, a similar dynamic of debate and engagement with NMP took place although within the Post Office and in the Royal Mail section there remained well into the $00 \mathrm{~s}$ a concern and uncertainty with new management techniques. In the case of the relevant union - the Communication Workers' Union the left used these critical debates as part of its repertoire of critiques of business unionism to significant shifts in the in the union's politics. For this reason the NMP debate can once again be seen as more than just a technical debate on the labour process with a variety of actors and interests having engaged in loose coalitions and networks (see Gall, 2001).

We are not saying that national union leaderships were straightforwardly successful in capturing this debate and developing a politics of incorporation into the ethos of lean production (Stewart, et al, 2009). Our argument is that a stream of academic debate embraced the rationale of NMP legitimising its de-politicisation and this chimed with the acceptance of NMP by trade union leaderships. The hegemonic moment in the isolation of critical voices became obvious not when there was no longer any space for social and 
political opposition for this never disappeared. The main factor pushing towards ideological and political marginalisation was the way alternative voices with NMP within the labour movement were marginalised in later discussions as being impractical. This was illustrated graphically when the leadership of one union (the TGWU) argued there was 'no alternative'. Nevertheless, experience showed people continued to question the discourse of 'no alternative', not just discursively, but materially in a range of sectors besides automotives that included postal services, food manufacturing, the Civil Service, secondary and tertiary education and the NHS.

During the timeframe discussed here, the production of union activist literature together with various seminars concerned with the causes, motives, nature and implications of management strategies within the workplace environment had a very high profile. The extent of discussion and literature on management initiatives in the automotive industry (Stewart, 1996), food manufacturing, the civil service and postal services (Gall, 1999), for example, cannot be underestimated and it constitutes a formidable set of formal texts and seminar materials which have rarely if ever been acknowledged. This activity and materials led to a growing network of activists, academics, and independent bodies and freelance researchers who framed discussions around issues such as team working and quality management. These individuals worked in many cases in an individual capacity or as part of networks in and around local levels of the union movement. In some cases they were involved in aspects such as teaching of local union representatives exposed to these changes in the nature of workplace organisation. They worked inside formal branches or local union education bodies. The research by the authors on various projects unearthed significant interventions, materials and courses developed by trade unionists to explain and challenge the development of new management practices. These communities and networks of activists are not uncommon, as Sciacchitano (2000) illustrates in her work on organising, in the forging of internal union debates and democratic pressures - consisting of shopfloor activists, trade union tutors, and labour oriented intellectuals - which help open perspectives on new themes and issues.

In the Ellesmere Port example above, representatives took on the task of setting up seminars and sessions for themselves and other local union representatives in the area. They also developed an international network around GM in Europe which held a series of seminars and workshops - whilst supported by the TGWU it was led from below and would have not developed without this local input. Similar initiatives could be seen in Rover (now BMW) Cowley where local activists linked to particular independent organisations and experts to develop an insight into the more pernicious aspects of organisational change within the workplace. In the Royal Mail this debate was driven by activists who linked the debate about Total Quality Management to the agenda for privatisation seeing the former very much as a precursor of the latter. These individuals set up networks and seminars within the union and parts of the academy.

This type of activity grew out of work also developed by trade union tutors. Such tutors in the TGWU and TUC, for example, had developed leaflets, booklets and courses on what new management practices were, on how to engage and critique them; much grew from engagement through health and safety courses in particular, which had begun to 
focus on issues of stress and fatigue at work. Whilst positions on the extent of their critique varied such tutors were an important link between the rank and file, broadly speaking, and the union organisation. They formed part of a network of individuals including trade unionists, independent bodies and academics who were concerned with such developments. To this extent these union activists and union tutors formed a body of organic intellectuals that pioneered the debate on new management practices (Gramsci, 1971). Unlike traditional intellectuals working under the illusion that they are autonomous and therefore outside the political or power process, labour organic intellectuals saw themselves as committed to a counter hegemonic agenda regarding new management practices and the relation between management and labour.

They argued in terms of autonomy of representation in the face of its increasing control by management, the need to raise issues of control and work intensification within the union and society, and the need to extend the debate towards broader issues of worker health and integrity (Stewart, 2006). They formed part of a web of individuals and bodies that criss-crossed and overcame boundaries between debates and institutions. To this extent the early debate on these subjects was propelled by local activists and union educators (and to a lesser degree sympathetic academics). The ability to cross social and institutional boundaries was a significant feature of such developments. What is more, the broad political dimension of local activist networks was also a factor (and one raised by Darlington, 2002 in his work on the role of political networks). However, the limited extent of official support received within these networks be they shopfloor representatives, tutors, and committed individuals meant that whilst influencing agendas they were unable to sustain a consistent critique within the labour movement. This was especially the case with the shift towards more conciliatory positions vis-à-vis NMP within various trade union leaderships. ${ }^{6}$

2: The Changing Parameters of the Discussion on NMP: the declining role of collective worker voices

It is clear that NMP has had overtly political and critical features as a debate within unions and on the shop floor: there have been a variety of participating voices but these have not always been registered. Regarding the changing nature of the debate on NMP and new forms of work organisation we can reflect on factors that have contributed variously to the way this has happened. Such reflection also includes an understanding as to why the inherent contradictions in the application of NMP may not lead to further conflict or tensions. The increasing contradictions in terms of health and safety with new forms of work organisation are becoming increasingly apparent within the workplace, but they may not become generalised in part due to political-organisational dynamics.

The trade union debate on work and employment has if anything mushroomed since then on a range of issues albeit framed in a less politically oriented way - that is to say with less concern with the motives of employers and the ambivalence of trade union politics and leadership. This can be recognised in three respects. Firstly, focus has shifted from production and operational processes, including their development. Specifically, the agenda is less concerned with issues of power and decision making in the labour process 
and more on access to employment, which is understandable given issues of social exclusion. Secondly, the question of motives and imperatives in terms of the nature of work and its re-design - where it comes from, who controls it, qui bono, and when appears to be less central to the trade union agenda. This is a bold statement and it is likely that these changes reflect the pressures on employment as it is widened around newer labour market and social agendas. Thirdly, the 'politics' of the discussion in terms of how involvement is crafted and re-crafted around managerial, individual and pseudocollective agendas and identities (Stewart, 2006) has been less pronounced.

In this regard, an important first point to note is that the social basis of the critical networks we describe and their discussion forums has been in some measure materially undermined. This has left an array of documentary material including histories and cases on the question of new management practices disconnected from an ongoing discussion regarding the nature of the labour process within the labour movement. Additionally, there may have been changes in the nature of the networks and their political profile; the importance of political or ideological networks in framing activist networks is an important observation made by Darlington (2004). More significantly, since many of the earlier debates were gendered, the gender effects of new working practices, such as the impact of new shift patterns on female workers, remained under-theorised and underrepresented within official and oppositional accounts (see Jenkins et al 2003). ${ }^{7}$

The second point to note, paralleling these developments is the increasing emphases on the outcomes of the labour process not the social form or the constitution of it. It is true that there is now a more sensitive and engaged debate within trade unions and the academy on questions related to the quality of work, the dignity of work, and the issue of rights at work which have effectively democratised the discussions and moved it from the closed constraints of traditional bargaining. Yet, rather than a concern with worker control, the question has steadily become regulates the new management developments. In the Anglo-Saxon context this may be due to the fact that collective voice mechanisms qua trade unions and collective bargaining are considered to be increasingly less salient. This steady shift away from the 1990s concern with workplace control and worker led industrial democracy has given the changing nature of the balance of forces and the challenge of new workplace issues (Martinez Lucio, 2010)). The question of organisational context and decision making does appear to be current in debates on corporate governance (Deakin et al, 2005) but these are often removed from the issues of micro level worker controls and trade union-led agendas of involvement-cum-decision making. In effect, it is not uncommon for us to be mesmerised by questions of impact and not direction or cause.

There is a further dimension to this issue of outcomes. The current interest in the question of performance and productivity within the study of Human Resource Management and Industrial Relations has developed in various directions. Increasingly the outcomes and performance of an organisation are discussed in terms of the 'ingredients' that influence performance (Huselid, 1995; Becker and Gerhart, 1996; Applebaum et al, 2000; Purcell, et al, 2003; The Work Foundation, 2003). The question of employee 'voice' and/or trade unions is inserted as a variable in the analysis of the 
effects they have on improving organisational performance (Applebaum et al, 2000), yet the impact on the workforce appears to be less salient as a research item as do union debates and politics on the topic. The research questions form around outcomes that are increasingly conceptualised in terms of economic or operational indicators and whilst much labour process debate has been and remains critical of such departures, one sees how this quantitative approach begins to shape the discussion around management strategy and practice in relation to workplace organisation through the High Performance Workplace Systems (HPWS) debate ${ }^{8}$. Unless it is in the critical literature (Lewchuk, 1997; Danford et al, 2004) discussion of worker health and social outcomes is increasingly marginal if it exits at all in the HPWS genre. The debate is framed in terms of finding mutual gains or common points of interest between management and labour such that the performance agenda can be wedded to a social agenda. Broader questions of participation and social ownership are rarely conceded so that participation tends to be reduced to questions of joint- or team- working (unlike the earlier work on social regimes of production as in Berggren, 1990).

Thirdly, this changing research agenda is seen in discussions of ownership and investment. The use of case study analysis in academia and in current trade union research in terms of where the research is generated tends to frame the experience of work with less than consistent references to questions of who owns the site, how they operate as a corporation and internationally, what are the driving motives and frameworks of control over time. Whilst in the study of multinational corporations there is growing sensitivity to these issues (Almond and Ferner, 2007), in terms of the study of the labour process within the workplace they are not always present. Amongst the reasons for this absence it may be argued that we cannot assume certain characteristics in terms of the management of the labour process by simply cross-referencing with the firm's capitalist character and profile. While valid, one does need to understand the economic pressures and financial regimes of any context and note how the question of work organisation may be linked to the logic of restructuring. The early debate on new management practices was more explicitly framed in terms of privatisation agendas, the emergence of new forms of inward investment, and the changing character of the firm in terms of its structure and strategy. It may have been that this was a moment of early 'globalisation' and 'commercialisation' that configured many of the concerns with the way competitive relations may have been developed in the workplace. The early debate on public sector change, new forms of Japanese inward investment (inter alia, Elger and Smith, 1994), and the restructuring programmes of multinational corporations began to be a focus of many of the discussions in the labour process debates. These concerns with the context of change have continued, yet the pressures of the contemporary academic labour process to produce case studies of change have in many instances contributed to the de-contextualisation of organisations from the context of political economy and ownership.

This requires a different analytical register and moreover one that recognises that previous understanding of NMP emerged from the nature of workplace debates including union and activist interventions: something that is clearly not present in current discussions where worker voice is individualised even when critical. Yet, we should 
remember this development is as much related to how these voices are represented, which is to link them to how social critique is framed politically in terms of resources, power and control. This, for sure, points to another dimension related to the way the question of knowledge and research are increasingly approached and to which we now turn.

\section{3) Politics, Research and Engagement in a Marketised Context}

The polyphony of voices within trade unions, research networks and universities and colleges (including TUC colleges) were and are, as we have argued, vital for sustaining a debate on not just what was happening to work but why. That the language and terminology varied is not the issue. A range of organic intellectuals created a debate that responded to intellectual and material needs. Yet there are dynamics, in terms of the way knowledge is created and presented, which influence the evolution of discussion on new management. The irony is that the very phenomenon that was studied has impacted on the way we research within trade unions and universities. The intensification of work and the increasing use of performance management techniques have impacted more widely. The pressures to produce and to gather particular kinds of knowledge have led to a more technicist approach in some cases. This is seen in terms of the changing research culture in universities and trade unions. It is not necessarily the case that this is a major, or sole, cause of the changing nature of the labour process debate, but we cannot discount the role of an increasingly 'productivist' culture of research framing a more fragmented research agenda around particular, isolated moments in the employment relationship.

Furthermore, the imperatives of funding and research monies can frame the way the research agenda is set even if there is more store placed on having 'practitioners' involved. The notion of practitioner is curious in relation to this discussion - it is clearly becoming a central feature of many academic funding bodies. It appears to connect research into the questions of 'end-users' and those who may be subjected to the research itself. However, the debate in the 1980s and 1990s had a very strong input from workplace activists and individuals who were not part of the professional union apparatus. While one can be accused of romanticising these development, the reality is that the role of workplace and branch based representatives and networks - linked as we saw previously to autonomous bodies and networks in Europe such as the TIE - meant that there was an active dialogue between individuals 'in the field' who were, moreover, concerned with transformation rather than principally, or straightforwardly, reform (or dare we say accommodation). It was, in other words, potentially uncontrollable and dynamic because it was not clearly institutional in hierarchical terms. In many respects, one can cross-reference this development with the way feminists have argued for over two decades now about the need to breakdown the hierarchical barriers between researchers and researched as these reflected an exploitative relationship in their own right between the former and the latter (Oakley, 1981).

The debate on NMPs whilst having distinct 'products' in terms of trade union, independent network and academic arenas did consist of joint work and discussions with the former playing a leading intellectual role. Yet recent notions of elite 'participants' and 'advisors' as part of the new funding criteria of such bodies as the publicly funded Economic and Social Research Council in the United Kingdom implicitly suggest that the 
participants are senior practitioners or known experts in the field thus reducing the relevance or impact of involving the type of local activists, organic intellectuals, of the labour movement that were involved in the types of cases we outlined previously. This may create a less reflexive and perhaps more 'professional'/'uncontentious' approach to research, which is linked to a lesser extent with the concerns, with the direct intervention, of the 'subjects' or 'participants' of the research environment. This could be considered amongst other factors to be one a series of developments helping with the mainstreaming of the NMPs debate. Yet this set of concerns about the direction of debates, reflected by the type of research methods utilised and the 'subject' of research itself, entails the need for an understanding of the way the politics and perspectives of workplace activists develop across time - and why at a particular moment in the late 1980s and early 1990s there was a network of critically engaged activists producing literature and materials. As we saw, these debates were not the outcome of academic intervention since they were driven in the first instance by the labour movement which included shop floor discourses of opposition to NMPs.

Our argument is that to understand the nature of these debates we need to renew our engagement with voices and practices from the shop floor. In addition to the tradition we have been describing, another is the response by the team of academics, trade unionists and community activists to the ICL-Stockline disaster (Beck et al 2007). To extend this type of engagement and scope for critique we need to consider anew what Lee (1995) describes as 'dangerous research'. Briefly, let us consider what this might mean for labour committed researchers of the labour process. As an exemplary note of caution for the realistic critic, we draw attention to a famous dilemma posed by, and cheerfully resolved, in Donald Roy's account of a participant's ethical dilemma during a labour dispute

"I made my decision. Sweating freely - it was a warm night - I ran back and forth with the strikers, stooping and swaying and swinging my arms in a balletic imitation of a man throwing rocks. [...] With my companions I made a rapid but dignified dash for my own automobile. The cops did not show up." (Roy, 1970:242)

Roy holds up as a virtue his decision not to do the unacceptable thing and break the law. Thus he ensures his virtue as a good researcher who stood above the fray while dissembling to his striking comrades who could not and moreover, failed to notice his pretence of partially playing the conflict game. He wants to be an observer when it comes to understanding labour organising strategies and he wants to participate-observe in some union actions. This is the classic role of the 'objective' researcher who can maintain the fiction of value neutrality because of a consensus on the place of the researcher in the micro context of the research setting. Yet, when it comes to something the researcher regards as law breaking good ethical researchers can somehow abstract themselves from the process. Even if the value neutral gaze were plausible, which we question, by deciding to avoid some actions and not others which are somehow compromising of the notion of ethnical neutrality; "Stooping and swaying and swinging my arms in a balletic imitation of a man throwing rocks..".this confected action only tells 
part of the story. While it cannot undo everything that was achieved by the researcher, nevertheless, it may even so compromise the participant observer since the reason for its utilisation is its reputed scope for lending deeper insight into the thinking and actions of the striker, the labour activist; the subject. Yet, arguably, it undermines the researcher's claim to deepen understanding, for, once this judgment of non-engagement is made, the participant observer may become the voyeuristic outsider unfamiliar with the politics and narratives of the local context.

This example raises critical issues about what it is as labour process researchers we are trying to achieve. Moreover, while sensitive to the undoubted physical dangers evident in a range of research encounters, it is not these that draw our attention so much as the supposed danger to our 'professional integrity' of 'over commitment'. The danger emerges as much in challenging the politically constructed boundaries between academics (observers) and workers (the observed). Moving in an out of others' labour process without recognizing what it is doing to one's own role and labour process is problematical. The labour process of research into the process of others' labour is arguably one of commitment, necessarily flowing from the fact of representation, and is no less ethically compromised when we seek to stand outside the struggles of others. This is a reasonable view from our perspective because otherwise one might think it acceptable to study workers and participate with them only in their oppression, but not in their opposition both individually and collectively through acts and narratives. That is to say that it can be considered fine to participate covertly (or even non-covertly) in working on the line, but not participate with workers when they want to smash it up.

Conclusion: recognising commitment and politics in the sociology of labour process $\underline{\text { research }}$

The introduction of 'Voices from the Front Line' in this journal (Taylor and Warhurst (2009) is an important departure in British sociology of work and employment and a commitment to engagement with labour raises critical issues about how to achieve this. First, we require recognition and the articulation of myriad dimensions of 'voices from the front line' including those perspectives relatively autonomous from 'official' voices; second, it is important we recognise that until recently this was indeed a feature of some research agendas both within and outside the academy, sometimes in alliance with the organic intellectuals of labour movement, including those in the workplace, and who have become less audible; third, we argue that being out of ear-shot is linked to a more widespread shift away from interest in the politics and texts of labour and its concerns, reflecting at one and the same time less curiosity within the academy and the official labour movement itself; finally, since 'independent voices' of labour remain inexplicable within the realm of the latter, discouraging as it does a research agenda premised on a rejection of oppositional voices and practices, commitment to these oppositional voices has to be an imperative if we are to capture the richness of workplace and worker debates and experiences.

Moreover, and arguably of greater salience, is the notion that if we can recognise the persistence of others' agendas - individual and collective voices from the front line - 
then a critical research agenda must seek to uncover these and, sometimes be alliance with those promoting them in the work place. Alliances with alternative and broader views is vital, and while not the preferred method of choice for all, recognition of the legitimacy of this approach is important if only because it allows for the airing of a range of perspectives and methodologies increasingly marginalized in 'official' research (Turner, 2007). This implies sympathy with Ossewaarde's description of the "contemporary new sociology" as a "moral and emancipatory enterprise", concerned with expressing, in our critical sociological way, the active voices of the marginalised and their collective views. It is this "enterprise" that for us leads to the possibility of a renewed research agenda in the sociology of work. Our view is that reinvigorating the sociology of work requires not only reflecting the voices of labour and giving radical and grounded accounts, but that reinvigoration also requires a new methodology of engagement. It requires a direct and more interactive form of working with those we are studying who do not have the resources, unlike management and employers, to have their views and positions represented. It also requires a genuinely democratic approach to issues of methodology, the recording of worker narratives, and a more sensitive realisation of collective interventions and not just the registering of individual concerns through brief dramatic statements sometimes taken out of context from the political and social realities of work.

\section{$\underline{\text { References }}$}

Almond, P. and Ferner, A. (2006) American Multinationals in Europe Oxford: OUP

Appelbaum, E., Bailey,T., Berg, P. and Kalleberg, A.L. (2000) Manufacturing Advantage: Why High Performance Work Systems Pay-Off Ithaca: New York

Beale, D. Driven By Nissan? A Critical Guide to New Management Techniques. Lawrence and Wishart, 1994.

Berggren, C (1993) Lean Production-The End of History? Work, Employment and Society, 7:2, 163-188 (1993)

Bourdieu, P (2003) Firing Back: Against the Tyranny of the Market, London, Verso

Brenner, M., Ferris, D., Ruser, J. (2004), “ "Flexible” work practices and occupational safety and health', Industrial Relations, Vol. 43 pp.242-66.

Burawoy, M (2005) 'For Public Sociology’, American Sociological Review 70 (1): 4-28.

Coffey, D (2006) The Myth of Japanese Efficiency: The World Car Industry in a Globalizing Age, Edward Elgar.

Darlington, R. (2002) 'Left wing activism and union organisation' Capital and Class, 2002; (76) pp 95-126. 
Deakin, S., Hobbs, R., Konzelmann, S.J. and Wilkinson, F. (2006) 'Working Corporations', M. and Martinez Lucio, M. (eds.) Partnership and the Modernisation of Employment Relations London: Palgrave

Delbridge, R., Turnbull, P., Wilkinson, B. (1992), "Pushing back the frontiers:

Management Control and Work Intensification Under JIT/TQM Factory Regimes", New

Technology, Work and Employment, Vol. 7 No.2, pp.97-106.

Darlington, R. (2002) 'Left wing activism and union organisation' Capital and Class, 2002; (76) pp 95-126.

Elger, T and Smith, C (1994) Global Japanisation, London: Routledge

Gall, G. (2001) 'The Organisation of Organised Discontent: the case of the postal workers in Britain' British Journal of Industrial Relations 39(2) 393-409.

Gottfried, H, (1992) 'In the Margins: Flexibility as a Mode of Regulation in the Temporary Help Service Industry', Work, Employment and Society, 6:3, 443-460.

Huselid, M.A. (1995) 'The Impact of HRM Practices on Turnover, Productivity and Corporate Financial Performance' Academy of Management Journal 38(3): 635-72

Jenkins, S. Martinez Lucio, M. and Noon, (2003) M. Return to Gender: An Analysis of Women's Disadvantage in Postal Work Gender, Work and Organisation 9(1) January 83104

Jones, D (1992) 'Lean Production (an update)', paper presented to the 'Lean Production and European Trade Union Co-operation', TGWU Centre - 6th-11th December 1992. Eastbourne, England.

Keenoy. T. (1990) 'HRM: A case of Wolf in Sheep's Clothing?' Personnel Review 19(2): 3-9

Lee R (1995) Dangerous Fieldwork, London: Sage

Lewchuk, W and Robertson, D (1996) 'Working Conditions under Lean Production: A Worker-based benchmarking Study’ Asia Pacific Business Review, Summer pp60-81.

Lewchuck, W. (1996)

Marchington, M. and Wilkinson, A (2000) Participation in Bach, S. and Sissons, K. (eds.) Personnel Management in Britain Oxford Blackwell

Martinez Lucio, M. (2010) 'Participation in Organizations and the End of the Political? Political Science - Labour Process and Marxist Perspectives' in Wilkinson, A and Marchington M (eds.) The Oxford Handbook of Organisational Participation Oxford: OUP 
Martinez Lucio, M. and Weston, S. 'The Politics and Complexity of Trade Union Responses to New Management Practices' Human Resource Management Journal, June $199277-91$

Martinez Lucio, M. and Weston, S. 'Trade Unions and Networking in the Context of Change: Evaluating the Outcomes of Decentralisation in Industrial Relations' Economic and Industrial Democracy, May 1995 233-252

Martinez Lucio, M., Noon, M. and Jenkins, S. (2000) 'The flexible-rigid paradox of the employment relationship at Royal Mail’: British Journal of Industrial Relations Journal, June 277-298

Oakley, A. (1981) 'Interviewing Women: a contradiction in terms,' in H. Roberts (ed) Doing Feminist Research. London: Routledge and Kegan Paul, pp. 30-61.

O'Connell Davidson, J. (1990 The Commercialisation of Employment Relations: The Case of the Water Industry. Work, Employment and Society 4: 531.

Oliver, N., Jones, D., Delbridge, R, and Lowe, J (1994) 'Worldwide Manufacturing Competitiveness Study' $2^{\text {nd }}$ Lean Enterprise Report, Andersen Consulting.

Ossewaarde, (2007) 'Sociology Back to the Publics'. Sociology. 41:5 pp799-812.

Purcell, J., Kinnie, N., Hutchinson, S., Rayton, B., Swart, J. (2003) Understanding the People and Performance Link: Unlocking the Black Box London: CIPD

Rinehart, J., Huxley, C. and Robertson, D. (1997) Just Another Car Factory? Lean Production and its Discontents, Ithaca and London: ILR Press.

Roy, D (1970) 'The study of southern labor union organizing campaigns' in R.W. Haberstein (ed) Pathways to data. Chicago: Aldine

Sciacchitano, K. (2000) 'Union Organising and Democracy: Living in One's Time, Building for Future’ Dissent Spring 75-81

Scott, A (1994) Willing Slaves? - British Workers Under Human Resource

Management, CUP.

Stewart, P. (2006) 'Individualism and Collectivism in the Sociology of the Collective Worker. in L.E. Alonso and M. Martinez Lucio (eds.) Employment relations in a Changing Society: . Basingstoke: Palgrave-Macmillan. 
Stewart, P. and Martinez Lucio, M. (1998) 'Renewal and Tradition in the Politics of Production' in Thompson and Warhurst (ed.) Workplaces of the Future London: Macmillan.

Stewart, P. Richardson, M, Danford, A, Murphy, K Richardson, T and Wass, V (2009) "We Sell Our Time No More. London: Pluto Press

Taylor, P. and Warhurst (2009) 'On the Front Line'. Work, Employment and Society, 22:1.March

Webb, J (1996) 'Vocabularies of Motive and the 'New' Management', Work, Employment \& Society, Vol. 10, No. 2, 251-271

Williams, K, Haslam, C and J Williams (1992) 'Ford versus 'Fordism': The Beginning of Mass Production?’ Work, Employment and Society, 6: 4, 517-555.

\footnotetext{
${ }^{1}$ See Stewart and Martinez Lucio (1998).

${ }^{2}$ See Stewart et al (2009) for a fuller discussion and Rinehart et al, (1997)

${ }^{3}$ TIE, based in Amsterdam is an independent body, working with trade unions on transnational and corporate related issues.

${ }^{4} 6-11^{\text {th }}$ December at Eastbourne

${ }^{5}$ See, inter alia, Lewchuk and Robertson, 1996; Rinehart et al, 1997; Brenner et al, 2004. The output of the CAW's research department was vital with perhaps the crucial CAMI report, 1993, which was developed by the Rinehart team, being the most significant in terms of the international attention it garnered. In the UK, see the Karel Williams team at Manchester and Coffey, 2006 in Leeds.

${ }^{6}$ The role of such networks varies across time. During the late 1990s and early 00s the wave of enthusiasm did in fact wane in the light of new industrial relations agendas around learning, formal participation and others. The emergence of such networks as Critical Labour Studies or the BUIRA Marxist Group reflects a new wave of debates and organic intellectuals tied to workplace and labour market (e.g. migration) related issues.

${ }^{7}$ The critical agendas may not have reflected the fact that there were 'defensive' and gendered orientations to male union activists' critiques of the development of NMP (see Jenkins et al 2003).

${ }^{8}$ Specifically, leading research bodies have since the 1990s inserted the issue of performance and productivity as a major element - and even pre-requisite for funding.
} 